\title{
Lactobacillus secaliphilus sp. nov., isolated from type II sourdough fermentation
}

Correspondence

Matthias A. Ehrmann

M.Ehrmann@wzw.tum.de

\author{
Matthias A. Ehrmann, ${ }^{1}$ Markus Brandt, ${ }^{2}$ Peter Stolz, ${ }^{2}$ Rudi F. Vogel ${ }^{1}$ \\ and Maher Korakli ${ }^{1}$ \\ ${ }^{1}$ Lehrstuhl für Technische Mikrobiologie, Technische Universität München, Weihenstephaner \\ Steig 16, D-85350 Freising, Germany \\ ²Ernst BÖCKER GmbH \& Co. KG Postfach 21, D-32378 Minden, Germany
}

Two strains of Gram-positive, catalase-negative, lactic acid bacteria, strains TMW $1.1309^{\top}$ and TMW 1.1313, were isolated at an interval of several years from an industrial type II sourdough. They occurred at cell numbers of $8 \times 10^{8}$ c.f.u. $\mathrm{g}^{-1}$ and therefore were considered to be one of the dominant members of the microbiota in this type of fermentation. Cells of both strains grow exclusively on modified MRS containing trypsin-digested rye-bran extract. Both strains possessed identical $16 \mathrm{~S}$ rRNA gene sequences, but could be discriminated by RAPD fingerprints. Comparative $16 \mathrm{~S}$ rRNA and tuf gene sequence analyses positioned strain TMW $1.1309^{\top}$ as part of the Lactobacillus reuteri phylogenetic group within the genus Lactobacillus. The 16S rRNA gene sequence similarities to the closest related species, Lactobacillus coleohominis and Lactobacillus ingluviei were 97.1 and $95.4 \%$, respectively. The DNA G +C content of strain TMW $1.1309^{\top}$ was $48 \mathrm{~mol} \%$. Growth characteristics, biochemical features and DNA-DNA hybridization values below $70 \%$ with all the nearest neighbours demonstrated that the isolates represent a novel Lactobacillus species. The name Lactobacillus secaliphilus sp. nov. is proposed for the novel isolates, with the type strain TMW $1.1309^{\top}\left(=\mathrm{DSM} 17896^{\top}=\right.$ CCUG $\left.53218^{\top}\right)$.
Sourdough is a mixture of flour and water that is fermented by lactic acid bacteria and used to improve the bakeability of rye and to ameliorate the dough properties, bread texture and flavour in doughs from other cereals (Corsetti et al., 1998; Hammes \& Gänzle, 1998; Rosenquist \& Hansen, 1998; Vogel et al., 1999). The typical bacterial microbiota of sourdough consists of various species of lactobacilli (Ehrmann \& Vogel, 2005). Its composition is highly dependent on physical fermentation parameters as well as the type of raw materials. Based on common principles used in artisanal and industrial processes, sourdoughs are classified as type I, II and III sourdoughs (Meroth et al., 2003).

\footnotetext{
Abbreviation: RAPD, randomly amplified polymorphic DNA.

The GenBank/EMBL/DDBJ accession numbers for the 16S rRNA gene sequences of strains TMW $1.1309^{\top}$ and TMW 1.1313 are AM279150 and AM411002, respectively. The GenBank/EMBL/ DDBJ accession numbers for the tuf gene sequences of $L$. mucosae DSM $13345^{\top}$, L. coleohominis CCUG $44007^{\top}$, L. secaliphilus DSM $17896^{\top}$, L. ingluviei DSM15946 ${ }^{\top}$, L. cellobiosus DSM 20055 ${ }^{\top}$, L. pontis DSM $8475^{\top}$, L. frumenti DSM $13145^{\top}$, L. panis DSM $6035^{\top}$ and $L$. oris DSM 4864 ${ }^{\top}$ are AM295057-AM295065, respectively.

Additional phylogenetic trees based on maximum-likelihood and maximum-parsimony analyses of the 16S rRNA gene sequence of strain TMW $1.1309^{\top}$ are available as supplementary figures in IJSEM Online.
}

Type I sourdoughs are characterized by continuous daily propagation at ambient temperatures of $20-30{ }^{\circ} \mathrm{C}$ resulting in a distinct tendency to a relatively high biodiversity. The predominant lactic acid bacterium in type I sourdoughs is Lactobacillus sanfranciscensis, but other species of the genera Weissella, Lactococcus, Leuconostoc and Enterococcus are also found (Rocha \& Malcata, 1999; Corsetti et al., 2001, 2003; De Vuyst et al., 2002; Ehrmann et al., 2003; Meroth et al., 2003; De Vuyst \& Neysens, 2005).

The industrialization of the baking process for rye bread has led to the development of type II sourdoughs, which serve mainly as dough acidifiers. Type II sourdoughs are fermented for long periods (up to 5 days) at temperatures of up to $50{ }^{\circ} \mathrm{C}$ and have a high water content. The species established in this environment are less numerous, differ from type I organisms and are highly adapted to the selective fermentation conditions. Key organisms of type II doughs include Lactobacillus pontis, Lactobacillus amylovorus, Lactobacillus frumenti and Lactobacillus panis (Vogel et al., 1994; Müller et al., 2000a, b). These cereal-associated lactobacilli are characterized by their strong thermotolerance and remarkable acid tolerance.

In the course of a study to comprehensively describe these microbiota, cultivation of micro-organisms was achieved using adaptations to standard media and growth conditions. 
To allow as many micro-organisms to grow as possible, we routinely used MRS that was enriched with cereal components, e.g. rye bran and malted wheat flour. Modified MRS (mMRS) medium was MRS supplemented with an aqueous extract of trypsin-digested rye-bran as described by Vogel et al. (1994). This rye-bran extract replaced $90 \%$ of the water of standard MRS. The rye-bran extract was prepared by incubation $\left(24 \mathrm{~h}\right.$ at $\left.50^{\circ} \mathrm{C}\right)$ of $40 \mathrm{~g}$ rye bran $\mathrm{l}^{-1}$, $2 \mathrm{~g}$ malted wheat meal $\mathrm{l}^{-1}$ and $0.8 \mathrm{~g}$ trypsin $\mathrm{l}^{-1}$ (SigmaAldrich) in water. The resulting turbid liquid was clarified by centrifugation ( $5000 \mathrm{~g}, 15 \mathrm{~min}$ ) and fluted paper filtration. Plated samples of a type II sourdough were incubated at $40{ }^{\circ} \mathrm{C}$ under a modified atmosphere $\left(90 \% \mathrm{~N}_{2} / 10 \% \mathrm{CO}_{2}\right.$, $\mathrm{v} / \mathrm{v})$. This strategy enabled us to isolate two novel strains, TMW $1.1309^{\mathrm{T}}$ and TMW 1.1313, which occurred at high cell numbers of $8 \times 10^{8}$ c.f.u. $\mathrm{g}^{-1}$ and were apparently some of the dominant members of the microbiota in this type of fermentation. Strain TMW $1.1309^{\mathrm{T}}$ was isolated several years before strain TMW 1.1313, but the fermentation conditions had remained unchanged.

Colonies of strains TMW $1.1309^{\mathrm{T}}$ and TMW 1.1313 appeared after 2-3 days of incubation and were typically small $(0.5-1 \mathrm{~mm}$ in diameter), flat and non-pigmented. This type of colony constituted about $10-20 \%$ of the total bacterial cell count in this fermentation. Other colonies were identified as L. amylovorus, L. pontis and L. frumenti.

Strains TMW $1.1309^{\mathrm{T}}$ and TMW 1.1313 were routinely cultivated on mMRS at $40^{\circ} \mathrm{C}$. The physiology, chemotaxonomy and phylogenetic positions of the novel isolates were analysed as described below.
Cell morphology was observed by phase-contrast microscopy with a light microscope (Zeiss) at $\times 1000$ with cells grown for 3 days at $40{ }^{\circ} \mathrm{C}$ on mMRS agar. Strains TMW $1.1309^{\mathrm{T}}$ and TMW 1.1313 subcultured on mMRS were able to grow at $35-45^{\circ} \mathrm{C}$, but not at $20^{\circ} \mathrm{C}$ or above $45^{\circ} \mathrm{C}$. No growth was observed on MRS or on Columbia blood agar. Both novel strains tolerate up to $30 \mathrm{~g} \mathrm{NaCl}^{-1}$. Both strains are obligately heterofermentative and $94 \pm 1.5 \%$ of total lactic acid produced is of the L configuration. Additional results of morphological, chemotaxonomical and physiological analyses are given in Table 1 and in the species description.

A sugar fermentation profile was determined using API 50 CHL galleries (bioMérieux) with some minor modifications. API inoculation medium was enriched by up to $40 \%$ with trypsin-digested rye-bran to allow growth of the strains. The $\mathrm{pH}$ was adjusted to 6.0. All tests were performed in duplicate. The formation of lactate isomers was determined enzymically using the DL-lactate test kit (Roche Diagnostics). Both strains produced acid from ribose. Strain TMW 1.1313 produced acid from sucrose.

The DNA G + C content was determined for strain TMW $1.1309^{\mathrm{T}}$ by HPLC analysis by the Deutsche Sammlung von Mikroorganismen und Zellkulturen (DSMZ, Germany) following the protocol previously described by Tamaoka $\&$ Komagata (1984). Wild-type $\lambda$ phage DNA was used as a standard (Mesbah et al., 1989). The peptidoglycan structure of the cell wall was determined by the DSMZ. The DNA $\mathrm{G}+\mathrm{C}$ content of strain TMW $1.1309^{\mathrm{T}}$ was $48 \mathrm{~mol} \%$, which is within the range of $32-55 \mathrm{~mol} \%$ previously reported for

Table 1. Physiological characteristics that differentiate strain $T M W 1.1309^{\top}$ and phylogenetic relatives of the genus Lactobacillus

Strains: 1, strain TMW $1.1309^{\mathrm{T}}$; 2, L. coleohominis DSM $14060^{\mathrm{T}}$ (data from Nikolaitchouk et al., 2001); 3, L. ingluviei DSM 15946 ${ }^{\mathrm{T}}$ (Baele et al., 2003); 4, L. thermotolerans DSM 14792 (Niamsup et al., 2003; Felis et al. 2006). +, Positive; -, negative; ND, not determined; V, variable, dependent on strain; W, weakly positive; $\mathrm{mDpm}$, meso-diaminopimelic acid.

\begin{tabular}{|lcccc|}
\hline Characteristic & $\mathbf{1}$ & $\mathbf{2}$ & $\mathbf{3}$ & $\mathbf{4}$ \\
\hline Acid produced from: & & & & \\
L-Arabinose & - & - & + & + \\
D-Fructose & - & $\mathrm{ND}$ & $+/-$ & + \\
Gluconate & - & $\mathrm{ND}$ & $\mathrm{W}$ & + \\
D-Glucose & - & + & $-/+$ & + \\
D-Maltose & - & + & $+/-$ & $\mathrm{ND}$ \\
Melibiose & - & - & + & + \\
D-Raffinose & - & - & $+/-$ & + \\
D-Ribose & + & + & + & + \\
Sucrose & $\mathrm{V}$ & - & + & - \\
Lactic acid isomer & $\mathrm{DL}$ & $\mathrm{DL}$ & $\mathrm{ND}$ & $\mathrm{DL}$ \\
Cell wall peptidoglycan & $\mathrm{A} 4 \alpha$ L-Lys-D-Asp & $\mathrm{Al} 1 \gamma, \mathrm{mDpm}$ & $\mathrm{ND}$ & $\mathrm{no} \mathrm{mDp}$ \\
DNA G + C content $(\mathrm{mol} \%)$ & 48 & $\mathrm{ND}$ & 49 & 50.5 \\
\hline
\end{tabular}

${ }^{*} 95 \%$ of total lactic acid is of the L configuration. 
Lactobacillus (Kandler \& Weiss, 1986). Analysis of the cellwall composition of strain TMW $1.1309^{\mathrm{T}}$ revealed the presence of lysine and aspartic acid, indicating the presence of the A4 $\alpha$ L-Lys-D-Asp peptidoglycan type.

To determine the phylogenetic position of strains TMW $1.1309^{\mathrm{T}}$ and TMW 1.1313, the 16S rRNA genes were sequenced over a continuous stretch of $1551 \mathrm{bp}$. Both sequences were identical. DNA was isolated according to a protocol described by Marmur (1961), except that lysis was performed overnight at $4{ }^{\circ} \mathrm{C}$. Amplification and sequencing of the 16S rRNA gene was carried as described by Müller et al. (2000a). The primer-binding sites of primers $616 \mathrm{~V}$ and 630R were at positions 8-27 and 1593-1608 of the 16S RNA gene sequence according to the Escherichia coli numbering system (Brosius et al., 1981). PCR products were purified by the QIAquick PCR purification kit (Qiagen) and were eluted with $60 \mu$ l elution buffer. DNA sequences were determined by the chain-termination method using the ABI Prism Dye Terminator Cycle sequencing kit (Perkin Elmer) on an ABI 373 stretch-sequencing system. The 16S rRNA gene sequences for the novel isolates (1518 bp) and sequences of reference strains retrieved from EMBL were aligned and a phylogenetic tree was constructed by the neighbour-joining method using the BioNumerics version 3.50 software package (Applied Maths). Unknown bases were discarded for the analyses. Bootstrapping analysis was undertaken to test the statistical reliability of the topology of the neighbour-joining tree using 500 bootstrap resamplings of the data (Fig. 1). Alternative treeing methods (maximumparsimony and maximum-likelihood) were also applied (see Supplementary Figs S1 and S2 available in IJSEM Online).

The highest gene sequence similarities, of 97.1 and $95.4 \%$, were obtained to the sequences of Lactobacillus coleohominis (GenBank accession no. AJ292530) and Lactobacillus ingluviei (AF333975), respectively (Fig. 1). These values clearly indicate that strain TMW $1.1309^{\mathrm{T}}$ belongs to the reuteri group of the genus Lactobacillus. A value of $95.0 \%$ gene sequence similarity was found between the novel strains and Lactobacillus thermotolerans. It was recently proposed that this species is a later synonym of L. ingluviei on the basis of its high genetic similarity (Felis et al., 2006). Lower sequence similarities $(<95 \%)$ were found with all other recognized species of the genus Lactobacillus. The use of additional treeing methods (maximum-parsimony and maximum-likelihood) resulted in essentially similar phylogenetic positions (see Supplementary Figs S1 and S2 in IJSEM Online).

Simultaneous comparisons of additional molecular markers from throughout the bacterial chromosome can achieve a higher resolution at the species level than 16S rRNA gene sequence data alone (Gevers et al., 2005). Even though the case for isolate TMW $1.1309^{\mathrm{T}}$ representing a separate species was clear on the basis of its $16 \mathrm{~S}$ rRNA gene sequence, we followed the trend towards multilocus sequence analyses and also included partial sequences for the elongation factor $\mathrm{Tu}$ in the phylogenetic analyses for a more robust classification at the species level. The tuf universal primers used to amplify a target region of $803 \mathrm{bp}$ were those previously described by Ke et al. (1999). A 735-bp portion of the tuf gene of strain TMW $1.1309^{\mathrm{T}}$ was sequenced (GenBank accession no. AM295059) and phylogenetic analysis was performed as described for the $16 \mathrm{~S}$ rRNA gene sequence data.

The topology obtained with the tuf gene sequences was not identical in every case with that based on the 16S rRNA gene sequence data (Fig. 2), but the tree obtained confirmed the separate species status of strain TMW $1.1309^{\mathrm{T}}$. As found in the 16S rRNA gene sequence analysis, the closest relative based on tuf sequences is L. coleohominis ( $90.78 \%$ sequence similarity). In contrast to the topology based on the $16 \mathrm{~S}$ rRNA gene sequence, $L$. panis and $L$. frumenti were the second closest relatives, each showing $88.3 \%$ gene sequence similarity. As expected, the tuf gene sequences were more discriminatory than the $16 \mathrm{~S}$ rRNA gene sequences.

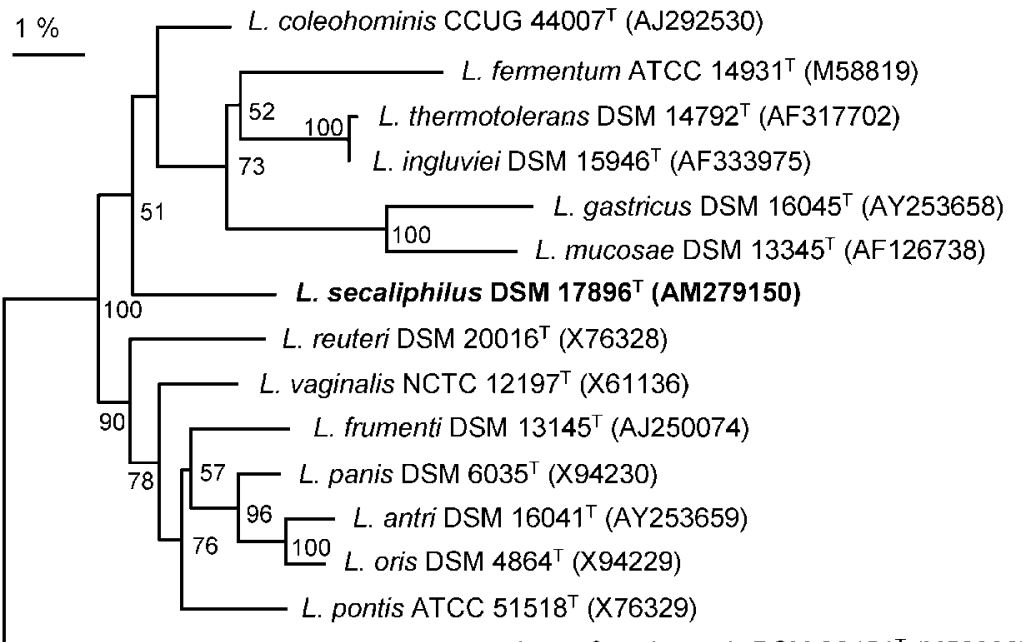

L. sanfranciscensis DSM $20451^{\top}$ (M58830)
Fig. 1. Neighbour-joining phylogenetic tree derived from 16S rRNA gene sequence analysis showing the relationship of $L$. secaliphilus sp. nov. to members of the Lactobacillus reuteri subgroup of lactobacilli. The sequence of $L$. sanfranciscensis was used as an outgroup. Approximately $1500 \mathrm{nt}$ from each sequence were used for the alignment. Numbers indicate bootstrap values $>50 \%$ (percentage of 500 replications). Bar, 1\% estimated sequence divergence. 


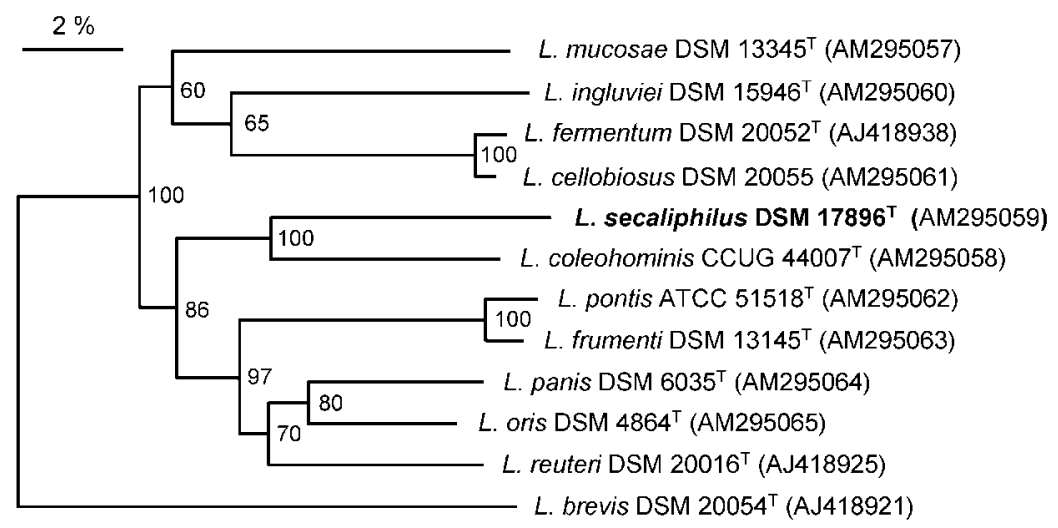

Fig. 2. Neighbour-joining phylogenetic tree obtained with partial sequences of the elongation factor Tu-encoding tuf gene showing the relationship of $L$. secaliphilus sp. nov. to members of the Lactobacillus reuteri subgroup of lactobacilli. The sequence of $L$. brevis was used as an outgroup. Approximately $735 \mathrm{nt}$ from each sequence were used for the alignment. Numbers indicate bootstrap values $>50 \%$ (percentage of 500 replications). Bar, $2 \%$ estimated sequence divergence.

In order to differentiate the two novel isolates, TMW $1.1309^{\mathrm{T}}$ and TMW 1.1313, a randomly amplified polymorphic DNA analysis (RAPD) was performed with the M13V primer (5'-GTTTTCCCAGTCACGAC-3') as described previously (Ehrmann et al., 2003). Strains TMW $1.1309^{\mathrm{T}}$ and TMW 1.1313 showed distinguishable fingerprints that demonstrated their genotypic differences (Fig. 3). DNAs of other species of lactobacilli showed quite different patterns.

DNA-DNA relatedness values were determined by using chromosomal DNA of strain TMW $1.1309^{\mathrm{T}}$ and its closest neighbours based on 16S rRNA gene sequence analysis, $L$. coleohominis and L. ingluviei. Renaturation kinetics were performed by the DSMZ following the protocol of De Ley et al. (1970), with modifications described by Huß et al. (1983) and Escara \& Hutton (1980). Experiments were performed in duplicate.

DNA-DNA relatedness values of strain TMW $1.1309^{\mathrm{T}}$ with L. coleohominis DSM $14060^{\mathrm{T}}$ and L. ingluviei DSM $15946^{\mathrm{T}}$ were 50.4 and $23.7 \%$, respectively. These values are far below the $70 \%$ threshold repeatedly recommended as the lowest value for isolates representing the same species (Wayne et al., 1987; Stackebrandt \& Goebel, 1994; RossellóMora \& Amann, 2001).

Taken together, the phenotypic and genotypic data presented here confirm that strains TMW $1.1309^{\mathrm{T}}$ and TMW 1.1313 represent a novel species, for which we propose the name Lactobacillus secaliphilus. The name reflects the need for rye extract to be added to the culture media to achieve growth of the novel species.

As a concluding remark, it may be mentioned that lactobacilli belonging to the phylogenetically defined Lactobacillus reuteri group are either found in association with the intestinal tracts and mucous membranes of humans (e.g. Lactobacillus vaginalis, Lactobacillus anstrumi, Lactobacillus gastricus, Lactobacillus oris, L. coleohominis and Lactobacillus mucosae) and many animals (e.g. L. ingluviei and L. thermotolerans) or in fermented cereals (L. pontis, $L$. panis, L. frumenti and L. secaliphilus sp. nov.). Only one species of the L. reuteri group has been found so far that is native to both of these environments. The prevailing conditions in these environments resemble each other in terms of similar temperatures, low $\mathrm{pH}$ and anaerobiosis and these conditions may lead to the selection of organisms of a closely defined phylogenetic group with similar physiological properties.

\section{Description of Lactobacillus secaliphilus sp. nov.}

Lactobacillus secaliphilus (se.ca.li.phi'lus. L. n. secale rye; Gr. adj. philos loving; N.L. masc. adj. secaliphilus rye-loving).

Cells are Gram-positive, non-motile, non-spore-forming rods that are $0.5-1 \mu \mathrm{m}$ in width and $2.0-4.0 \mu \mathrm{m}$ in length and occur singly, in pairs or in filaments. When the organism is grown on mMRS agar at $37^{\circ} \mathrm{C}$ for 2 days,

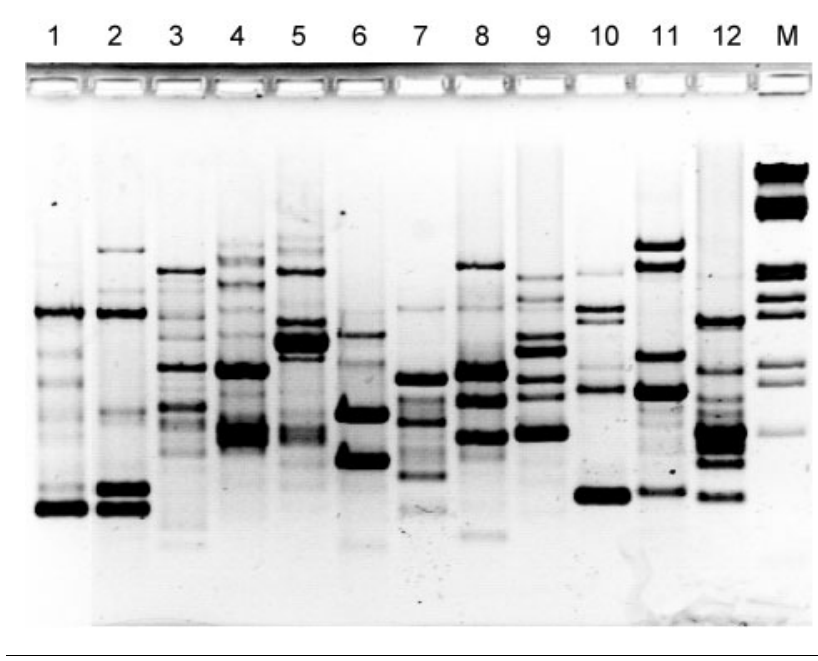

Fig. 3. $M 13$ RAPD-fingerprint of $L$. secaliphilus strains and other related lactobacillus species. $1, L$. secaliphilus TMW $1.1309^{\top} ; 2$, L. secaliphilus TMW 1.1313; 3, L. coleohominis DSM $14060^{\top}$; 4, L. ingluviei DSM $15946^{\top}$; 5 , L. panis DSM $6035^{\top} ; 6$, L. pontis DSM $8475^{\top} ; 7, L$ reuteri DSM $20016^{\top} ; 8$, L. frumenti DSM $13145^{\top} ; 9$, L. mucosae TMW 1.81; 10, L. vaginalis DSM $5837^{\top} ; 11$, L. oris DSM $4864^{\top} ; \mathrm{M}$, size marker (marker III, MBI Fermentas). 
colonies are small (0.5-1 $\mathrm{mm}$ in diameter), colourless, circular to slightly irregular to rough and flat in form. No growth is observed at $15^{\circ} \mathrm{C}$ or at $45^{\circ} \mathrm{C}$. The organism is facultatively anaerobic and produces almost only L-lactic acid $(94 \%)$ heterofermentatively. Catalase is not produced. Growth occurs in up to $3 \% \mathrm{NaCl}$. Acid is produced from Dribose. Acid production from sucrose is variable. Acid is not produced from D-glucose, L-arabinose, L-sorbose, L-rhamnose, D-mannitol, D-sorbitol, methyl $\beta$-D-glucoside, salicin, D-cellobiose, D-fructose, melibiose, melezitose, lactose, Draffinose, maltose, galactose, $\mathrm{D}$-xylose, $\beta$-gentiobiose, gluconate or D-turanose. The DNA G $+\mathrm{C}$ content of the type strain is $48 \mathrm{~mol} \%$. The peptidoglycan type is $\mathrm{A} 4 \alpha$ (L-Lys-D-Asp).

The type strain, TMW $1.1309^{\mathrm{T}}\left(=\mathrm{DSM} 17896^{\mathrm{T}}=\mathrm{CCUG}\right.$ $53218^{\mathrm{T}}$ ), was isolated from a type II sourdough in Germany.

\section{Acknowledgements}

We thank Monika Hadek, Georg Maier and Oliver Luft for their excellent technical assistance. We gratefully acknowledge Hans G. Trüper for his advice regarding the correct nomenclature.

\section{References}

Baele, M., Vancanneyt, M., Devriese, L. A., Lefebvre, K., Swings, J. \& Haesebrouck, F. (2003). Lactobacillus ingluviei sp. nov., isolated from the intestinal tract of pigeons. Int J Syst Evol Microbiol 53, 133-136.

Brosius, J., Dull, T. J., Sleeter, D. D. \& Noller, H. (1981). Gene organization and primary structure of a ribosomal RNA operon from Escherichia coli. J Mol Biol 148, 107-127.

Corsetti, A., Gobbetti, M., Balestrieri, F., Paoletti, F., Russi, L. \& Rossi, J. (1998). Sourdough lactic acid bacteria effects on bread firmness and staling. J Food Sci 63, 347-351.

Corsetti, A., Lavermicocca, P., Morea, M., Baruzzi, F., Tosti, N. \& Gobbetti, M. (2001). Phenotypic and molecular identification and clustering of lactic acid bacteria and yeasts from wheat (species Triticum durum and Triticum aestivum) sourdoughs of Southern Italy. Int J Food Microbiol 64, 95-104.

Corsetti, A., De Angelis, M., Dellaglio, F., Paparella, A., Fox, P. F., Settanni, L. \& Gobbetti, M. (2003). Characterization of sourdough lactic acid bacteria based on genotypic and cell-wall protein analyses. J Appl Microbiol 94, 641-654.

De Ley, J., Cattoir, H. \& Reynaerts, A. (1970). The quantitative measurement of DNA hybridization from renaturation rates. Eur J Biochem 12, 133-142.

De Vuyst, L. \& Neysens, P. (2005). The sourdough microflora: biodiversity and metabolic interactions. Trends Food Sci Technol 16, 43-56.

De Vuyst, L., Schrijvers, V., Paramithiotis, S., Hoste, B., Vancanneyt, M., Swings, J., Kalantzopoulos, G., Tsakalidou, E. \& Messens, W. (2002). The biodiversity of lactic acid bacteria in Greek traditional wheat sourdoughs is reflected in both composition and metabolite formation. Appl Environ Microbiol 68, 6059-6069.

Ehrmann, M. A. \& Vogel, R. F. (2005). Molecular taxonomy and genetics of sourdough lactic acid bacteria. Trends Food Sci Technol $16,31-42$
Ehrmann, M. A., Müller, M. R. A. \& Vogel, R. F. (2003). Molecular analysis of sourdough reveals Lactobacillus mindensis sp. nov. Int J Syst Evol Microbiol 53, 7-13.

Escara, J. F. \& Hutton, J. R. (1980). Thermal stability and renaturation of DNA in dimethyl sulfoxide solutions: acceleration of the renaturation rate. Biopolymers 19, 1315-1327.

Felis, G. E., Vancanneyt, M., Snauwaert, C., Swings, J., Torriani, S., Castioni, A. \& Dellaglio, F. (2006). Reclassification of Lactobacillus thermotolerans Niamsup et al. 2003 as a later synonym of Lactobacillus ingluviei Baele et al. 2003. Int J Syst Evol Microbiol 56, 793-795.

Gevers, D., Cohan, F. M., Lawrence, J. G., Spratt, B. G., Coenye, T., Feil, E. J., Stackebrant, E., Van de Peer, Y., Vandamme, P. \& other authors (2005). Opinion: Re-evaluating prokaryotic species. Nat Rev Microbiol 3, 733-739.

Hammes, W. P. \& Gänzle, M. G. (1998). Sourdough breads and related products. In Microbiology of Fermented Foods, vol. 1, pp. 199-216. Edited by B. J. B. Woods. London: Blackie.

Huß, V. A. R., Festl, H. \& Schleifer, K. H. (1983). Studies on the spectrophotometric determination of DNA hybridization from renaturation rates. Syst Appl Microbiol 4, 184-192.

Kandler, O. \& Weiss, N. (1986). Genus Lactobacillus Beijerinck 1901, $212^{\mathrm{AL}}$. In Bergey's Manual of Systematic Bacteriology, vol. 2, pp. 1209-1234. Edited by P. H. A. Sneath, N. S. Mair, M. E. Sharpe \& J. G. Holt. Baltimore: Williams \& Wilkins.

Ke, D., Picard, F. J., Martineau, F., Menard, C., Roy, P. H., Ouellette, M. \& Bergeron, M. G. (1999). Development of a PCR assay for rapid detection of enterococci. J Clin Microbiol 37, 3497-3503.

Marmur, J. (1961). A procedure for the isolation of deoxyribonucleic acid from microorganisms. J Mol Biol 3, 208-218.

Meroth, C. B., Walter, J., Hertel, C., Brandt, M. J. \& Hammes, W. P. (2003). Monitoring the bacterial population dynamics in sourdough fermentation processes by using PCR-denaturing gradient gel electrophoresis. Appl Environ Microbiol 69, 475-482.

Mesbah, M., Premachandran, U. \& Whitman, W. B. (1989). Precise measurement of the $\mathrm{G}+\mathrm{C}$ content of deoxyribonucleic acid by highperformance liquid chromatography. Int J Syst Bacteriol 39, 159-167.

Müller, M. R. A., Ehrmann, M. A. \& Vogel, R. F. (2000a). Lactobacillus frumenti sp. nov., a new lactic acid bacterium isolated from rye-bran fermentations with a long fermentation period. Int J Syst Evol Microbiol 50, 2127-2133.

Müller, M. R. A., Ehrmann, M. A. \& Vogel, R. F. (2000b). Multiplex PCR for the detection of Lactobacillus pontis and two related species in a sourdough fermentation. Appl Environ Microbiol 66, 2113-2116.

Niamsup, P., Sujaya, I. N., Tanaka, M., Sone, T., Hanada, S., Kamagata, Y., Lumyong, S., Assavanig, A., Asano, K. \& other authors (2003). Lactobacillus thermotolerans sp. nov., a novel thermotolerant species isolated from chicken faeces. Int J Syst Evol Microbiol 53, 263-268.

Nikolaitchouk, N., Wacher, C., Falsen, E., Andersch, B., Collins, M. D. \& Lawson, P. A. (2001). Lactobacillus coleohominis sp. nov., isolated from human sources. Int J Syst Evol Microbiol 51, 2081-2085.

Rocha, J. M. \& Malcata, F. X. (1999). On the microbiological profile of traditional Portuguese sourdough. J Food Prot 62, 1416-1429.

Rosenquist, H. \& Hansen, A. (1998). The antimicrobial effect of organic acids, sour dough and nisin against Bacillus subtilis and $B$. licheniformis isolated from wheat bread. J Appl Microbiol 85, 621-631.

Rosselló-Mora, R. \& Amann, R. (2001). The species concept for prokaryotes. FEMS Microbiol Rev 25, 39-67.

Stackebrandt, E. \& Goebel, B. M. (1994). Taxonomic note: a place for DNA-DNA reassociation and $16 \mathrm{~S}$ rRNA sequence analysis in the 
present species definition in bacteriology. Int J Syst Bacteriol 44, 846-849.

Tamaoka, J. \& Komagata, K. (1984). Determination of DNA base composition by reversed-phase high-performance liquid chromatography. FEMS Microbiol Lett 25, 125-128.

Vogel, R. F., Böcker, G., Stolz, P., Ehrmann, M., Fanta, D., Ludwig, W., Pot, B., Kersters, K., Schleifer, K. H. \& Hammes, W. P. (1994). Identification of lactobacilli from sourdough and description of Lactobacillus pontis sp. nov. Int J Syst Bacteriol 44, 223-229.
Vogel, R. F., Knorr, R., Müller, M. R. A., Steudel, U., Gänzle, M. G. \& Ehrmann, M. (1999). Non-dairy lactic fermentations: the cereal world. Antonie van Leeuwenhoek 76, 403-411.

Wayne, L. G., Brenner, D. J., Colwell, R. R., Grimont, P. A. D., Kandler, O., Krichevsky, M. I., Moore, L. H., Moore, W. E. C., Murray, R. G. E. \& other authors (1987). International Committee on Systematic Bacteriology. Report of the ad hoc committee on reconciliation of approaches to bacterial systematics. Int $J$ Syst Bacteriol 37, 463-464. 